\title{
Evaluation of Native and Introduced Grasses for Reclamation and Production
}

\author{
Walter D. Willms, ${ }^{1}$ Ben H. Ellert, ${ }^{2}$ H. Henry Janzen, ${ }^{3}$ and \\ Harriet Douwes ${ }^{4}$ \\ Authors are ${ }^{1}$ Range Ecologist, ${ }^{2}$ Soil Scientist, ${ }^{3}$ Soil Biochemist, and ${ }^{4}$ Range Technician, \\ Agriculture and AgriFood Canada, Lethbridge, Alberta, Canada T1J 4 B1.
}

\begin{abstract}
Crested wheatgrass (Agropyron cristatum [L.] Gaertn.) and Russian wildrye (Elymus junceus Fisch.) are commonly used for reseeding in the more xeric Mixed Prairie of the Canadian prairies because they are perceived to be more productive than native species. However, they have been implicated in soil deterioration. The objectives of our study were to compare the aboveground net primary production and soil organic carbon (C) among monoculture communities of selected native grass species, crested wheatgrass, and Russian wildrye and to compare the native grass monocultures with their mixtures. In 1995, a 5-year study was initiated on Dark Brown Chernozemic (Typic Haploboroll) soil near Lethbridge, Alberta. Ten treatments consisting of monocultures of introduced and selected native species and mixtures of native species were established in a randomized complete block design with 4 replications. Aboveground net primary production and soil organic C were measured. Monocultures of 2 native species, green needlegrass (Stipa viridula Trin.) and blue grama (Bouteloua gracilis [H.B.K.] Lag. ex Steud.), were more productive than crested wheatgrass or Russian wildrye under both normal moisture and drought conditions. Monocultures of these native species also tended to be more productive than their mixtures. The western wheatgrass (A. smithii Rydb.) monoculture and the western wheatgrass-blue grama mixture experienced the greatest yield reduction as a result of drought. Treatment effects on soil organic $\mathrm{C}$ were not detected $(P>0.05) 5$ years after seeding. Soils of the June grass (Koeleria macrantha [Ledeb.] J.A. Schultes f.) community had less $(P<0.05)$ macro-organic $\mathrm{C}$ than most other treatments.
\end{abstract}

\section{Resumen}

El "Crested wheatgrass" (Agropyron cristatum [L.] Gaertn.) y "Russian wildrye” (Elymus junceus Fisch.) son comúnmente utilizados para la resiembra en las praderas mixtas más xéricas del Canadá porque se percibe que son mas productivas que las especies nativas; sin embargo, ellas han sido implicadas en el deterioro del suelo. Los objetivos de nuestro estudio fueron comparar la producción primaria neta aérea y el C orgánico del suelo entre comunidades de monocultivo de especies nativas seleccionadas, "Crested wheatgrass," y "Russian wildrye" y comparar los monocultivos de especies nativas con sus mezclas. En 1995, se inicio un estudio de 5 años en un suelo Chernozem café obscuro (Haploboroll típico) cercano a Lethbridge, Alberta. Diez tratamientos consistentes del monocultivos de las especies introducidas y especies nativas seleccionadas y de mezclas de especies nativas se establecieron bajo un diseño de bloques completos al azar con 4 repeticiones. La producción primaria neta aérea y el C orgánico del suelo fueron medidos. Los monocultivos de 2 especies, "Green needlegrass" (Stipa viridula Trin.) y "Blue grama" (Bouteloua gracilis [H.B.K.] Lag. ex Steud.), fueron más productivos que "Crested wheatgrass" o "Russian wildrye" tanto en condiciones normales de humedad como en condiciones de sequía, los monocultivos de estas especies también tendieron a ser mas productivas que sus mezclas. El monocultivo de "Western wheatgrass" (A. smithii Rydb.) y la mezcla de "Western wheatgrass-Blue grama" presentaron la mayor reducción de rendimiento como resultado de la sequía. Después de 5 años de sembrados los tratamientos no se detectaron efectos en el carbón orgánico del suelo $(P>0.05)$. Los suelos dende se encontraba la comunidad de "June grass" (Koeleria macrantha [Ledeb.] J.A. Schultes f.) tuvieron menos $(P<0.05)$ carbón macro-orgánico que el resto de los tratamientos.

Key Words: soil organic carbon, aboveground primary production, crested wheatgrass, Russian wildrye, green needlegrass, western wheatgrass, blue grama, June grass

\section{INTRODUCTION}

Crested wheatgrass (Agropyron cristatum [L.] Gaertn.) and Russian wildrye (Elymus junceus Fisch.) are commonly used for forage production in the Northern Great Plains (Smoliak and Dormaar 1985). Crested wheatgrass is desirable for reclamation because it establishes readily, but its use has been criti-

Correspondence: Walter D. Willms, Agriculture and AgriFood Canada, P0 Box 3000, Lethbridge, Alberta, Canada T1J 4B1. Email: willms@agr.gc.ca

Manuscript received 14 May 2003; manuscript accepted 21 September 2004. cized because of perceived detrimental impacts on soil quality (Dormaar et al. 1978; Lesica and DeLuca 1996). Consequently, native grasses are being examined with increasing interest in Alberta for their potential use in reclamation and forage production (Watson et al. 1980; Kerr et al. 1993). Native grasses are adapted to a broad range of soil and climatic conditions found in the Northern Great Plains and can be exploited for commercial purposes in forage production or soil reclamation. Nevertheless, Lawrence and Ratzlaff (1989) asserted that research efforts should be directed toward introduced, rather than native, species because the former were more productive. 
Table 1. Seeding rate and estimated density of germinable seeds applied by hand-broadcasting; average seed density of total and germinable seed broadcast in 1995.

\begin{tabular}{|c|c|c|c|c|c|c|c|c|}
\hline \multirow{3}{*}{ Species } & \multirow{3}{*}{$\begin{array}{l}\text { Germinable } \\
\text { Seeds }^{1}(\%)\end{array}$} & \multirow{3}{*}{$\begin{array}{c}\text { Seeding } \\
\operatorname{Rate}^{2}\left(\mathrm{~kg} \cdot \mathrm{ha}^{-1}\right)\end{array}$} & \multicolumn{3}{|c|}{ Total Seeds } & \multicolumn{3}{|c|}{ Germinable Seeds } \\
\hline & & & \multicolumn{3}{|c|}{ Proportion in Mix } & \multicolumn{3}{|c|}{ Proportion in Mix } \\
\hline & & & 100 & 50 & 33 & 100 & 50 & 33 \\
\hline Agropyron smithii & 2 & 41 & 2100 & 1040 & 700 & 42 & 21 & 14 \\
\hline Bouteloua gracilis & 41 & 41 & 17800 & 8800 & 5900 & 7300 & 3600 & 2400 \\
\hline Elymus junceus & 86 & 36 & 3030 & na & na & 2600 & na & na \\
\hline Agropyron cristatum & 88 & 36 & 3030 & na & na & 2700 & na & na \\
\hline
\end{tabular}

${ }^{1}$ Germinability determined by the number of germinated seeds after 40 days in a laboratory for the native species and from the seed testing certificate of the introduced species.

${ }^{2}$ Rate applied as monoculture; in seed combinations, the weight is reduced by its proportion in the mix.

${ }^{3}$ na indicates not applicable for the treatments tested.

The comparisons of seeded monocultures with diverse native grasslands are influenced by species that exhibit different functional and morphological traits. For example, crested wheatgrass, western wheatgrass (Agropyron smithii Rydb.), and blue grama (Bouteloua gracilis [H.B.K.] Lag. ex Steud.) exhibited different releases of $\mathrm{C}$ and nitrogen $(\mathrm{N})$ in their root exudates and a different dependency on the presence of rhizosphere microflora (Biondini et al. 1988), whereas communities having greater diversity tended to be more productive because of niche complementarity among species (Tilman et al. 2001). Therefore, comparisons between native communities and introduced species grown as monocultures cannot lead to general conclusions on their relative productivities.

To better understand the influence of plant species on grassland productivity and soil carbon, we compared monocultures of introduced and native grasses, as well as simple mixtures of native species. We tested the hypothesis that aboveground net primary production and soil carbon storage were enhanced with native species and increased biodiversity.

\section{METHODS}

The study site was near Lethbridge, Alberta, Canada (lat $49^{\circ} 43^{\prime} \mathrm{N}$, long $112^{\circ} 41^{\prime} \mathrm{W}$ ) on a 2 -year-old stand of irrigated alfalfa (Medicago sativa L.) that had previously been under a mixture of smooth brome (Bromus inermis Leyss.), orchardgrass (Dactylis glomerata L.), and Kentucky bluegrass (Poa pratensis L.). The site had been used for fall grazing. The site was prepared in 1995 for seeding with 2 applications of Roundup (on 11 May and on 1 June), followed by plowing and repeated discing and harrowing to control weeds. From 11 July 1995 to 13 July 1995 , 10 treatments were established that consisted of monocultures of green needlegrass (Stipa viridula Trin.), blue grama, western wheatgrass, June grass (Koeleria macrantha [Ledeb.] J. A. Schultes f.), Russian wildrye var. Cabree, and crested wheatgrass var. Fairway and mixtures of green needlegrass, blue grama, and western wheatgrass. The 4 native species offered functional diversity with respect to physiology $\left(\mathrm{C}_{3}\right.$ vs. $\left.\mathrm{C}_{4}\right)$, morphology (rhizomatous vs. tufted), and succession (mid- vs. late-seral community). The seed of all native species were harvested from natural grasslands using a flail and were cleaned at a commercial facility. The treatments were seeded in a randomized complete block design (in $7 \times$ 24-m plots and 4 blocks) to account for potential soil variability caused by a shallow slope.

Of the species tested, only Russian wildrye and crested wheatgrass are nonnative. The only rhizomatous species tested was western wheatgrass, whereas all others are tufted or only weakly rhizomatous. All species except blue grama have a $\mathrm{C}_{3}$ pathway. June grass and blue grama are small plants in relation to the other species tested.

Plots within a block were contiguous but the blocks were separated with a 4-m-wide seeded path. The seed was applied by broadcasting and then packed with a roller. The seeding rate of the introduced species was about 4 times the recommended rate (Alberta Agriculture Food and Rural Development 2001). Although comparable recommendations were not available for native species, they were seeded at rates that were higher than the introduced species (Table 1). The high seeding rates were designed to compensate for broadcast seeding, which is more risky than drilling; to circumvent the high inherent dormancy that is prevalent in native species; and to achieve rapid establishment of the community (Table 1). The site was irrigated in the establishment year, and all plots were treated with a mixture of 2,4-D ( $\left.1 \mathrm{~L} \cdot \mathrm{ha}^{-1}\right)$ and Banvel $\left(265 \mathrm{~mL} \cdot \mathrm{ha}^{-1}\right)$ on 23 May 1996 and again on 8 July 1996 to control volunteer plants. The plots were examined every spring, and invasive plants were removed.

Growing season precipitation was above average in 1995, 1997, and 1998; near average in 1999; and about $50 \%$ of average in 1996 and 2000 (Table 2). The monthly mean of average daily temperatures was above average in 1996, 1998, and 2000; near average in 1997 and 1999; and below average in 1995.

\section{Vegetation Sampling}

Treatment establishment was documented in surveys of foliar ground cover, estimated using the Daubenmire (1959) scale, and conducted in July of 1996, 1997, 1999, and 2000. We calculated an average foliar cover of each species from a sample of 10 quadrats $(20 \times 50 \mathrm{~cm})$ along a single transect oriented lengthwise in the center of each plot. Because the estimate is based on foliar cover, the total cover could exceed $100 \%$. Bare 
soil was estimated as that portion not occupied by the basal areas of plants.

Annual net primary production of both introduced and native grass treatments were estimated at peak standing crop by harvesting two $0.25-\mathrm{m}^{2}$ subplots $(0.5 \times 0.5 \mathrm{~m})$ near ground level and separating the litter (previous years' production). However, the sampling schedules differed to account for differences in phenology and plot management. Therefore, crested wheatgrass and Russian wildrye were harvested within the last 2 weeks of June before seed shatter whereas the native treatments were harvested in late July or early August. Following sampling, the entire plot was mowed at a stubble height of $9 \mathrm{~cm}$, and the herbage baled and removed. This strategy prevented encroachment from crested wheatgrass and Russian wildrye into adjacent plots while harvesting each treatment at peak standing crop. Peak standing crop in crested wheatgrass occurred by early May, with no further regrowth after midMay, in an environment similar to that of the current study (Romo and Harrison 1999).

\section{Soil Sampling and Analyses}

In spring 2000,3 or 6 soil cores $(6.7 \times 60 \mathrm{~cm})$, were taken in increments of $0-7.5,7.5-15,15-30,30-45$, and $45-60 \mathrm{~cm}$ of soil depth from each treatment plot. In monoculture treatments, 3 cores were taken from under bare soil, and each was paired with cores taken within $50 \mathrm{~cm}$ under the crowns of grass plants. The subsamples were pooled by depth increment and sampling location. In the mixed-species treatments, 2 cores were taken from under the crowns of grass plants ( 1 from each of the dominant grass species) and 1 from under bare soil and were pooled across sampling location by depth increment. Cores were taken after removing any surface litter or clipping plants to about $1 \mathrm{~cm}$ from the soil surface.

The soil samples were placed into plastic bags and brought to a field building for processing. The total weight of field-moist soil was recorded. The cores were then broken up, mixed, and subsampled (70-90 g). Coarse fragments of organic matter (macro-organic matter) and stones $(>2 \mathrm{~mm}$ in diameter) were removed from the subsample, which was then dried at $105^{\circ} \mathrm{C}$ to determine gravimetric field-moisture content and, subsequently, bulk density. The soil samples were spread on foil trays for several days to facilitate air-drying before they were enclosed in plastic bags to prevent contamination while awaiting further processing. The samples were prepared by removing plant crowns, consisting of tufts of shoots and roots, and physically fractionating using a sieving $(0.85-\mathrm{mm}$ mesh) and winnowing technique to yield macro-organic matter, mineral soil (which includes organic matter smaller than $0.85 \mathrm{~mm}$ ), and stones greater than $2 \mathrm{~mm}$. The macro-organic matter is essentially the coarse fragments of plant roots and residues. The mineral soil was ground on a roller mill, thoroughly mixed, and a 5-g subsample taken. The crowns, macro-organic matter, and subsample were dried $\left(60^{\circ} \mathrm{C}\right)$ to constant mass.

Crown and macro-organic matter were ground to pass through a 1-mm sieve using a Thomas-Wiley mill (Thomas Scientific, Hoboken, NJ) or a Retsch cutting mill (Haan, Germany), then passed through a UDY Cyclone mill (Fort Collins, CO) equipped with a $0.5-\mathrm{mm}$ screen. Organic $\mathrm{C}$ in mineral soil, macro-organic matter, and crown samples were
Table 2. Monthly precipitation and average temperature over the growing season at Lethbridge, Alberta, Canada, from 1995 to 2000.

\begin{tabular}{lrrrrrc}
\hline & April & May & June & July & August & Total \\
\cline { 2 - 7 } Year & \multicolumn{5}{c}{ Precipitation $(\mathrm{mm})$} \\
\hline 1995 & 38 & 106 & 138 & 66 & 44 & 392 \\
1996 & 21 & 22 & 54 & 18 & 5 & 120 \\
1997 & 14 & 96 & 101 & 32 & 33 & 276 \\
1998 & 42 & 53 & 148 & 57 & 36 & 336 \\
1999 & 42 & 58 & 65 & 64 & 39 & 268 \\
2000 & 34 & 11 & 45 & 6 & 27 & 123 \\
99 yr average & 31 & 54 & 74 & 42 & 41 & 242 \\
& & & & & & \\
& & & & & & \\
1995 & 4.3 & 10.1 & 14.6 & 17.3 & 15.8 & 12.4 \\
1996 & 7.4 & 8.8 & 15.7 & 18.5 & 19.6 & 14.0 \\
1997 & 3.9 & 11.3 & 16.0 & 18.2 & 18.6 & 13.6 \\
1998 & 8.0 & 13.7 & 14.4 & 20.3 & 20.2 & 15.3 \\
1999 & 6.1 & 10.3 & 14.6 & 16.4 & 18.8 & 13.2 \\
2000 & 6.6 & 12.2 & 15.4 & 19.8 & 18.7 & 14.5 \\
99 yr average & 5.6 & 10.8 & 14.9 & 18.0 & 17.1 & 13.3 \\
\hline
\end{tabular}

determined, after first acidifying to eliminate the carbonates, by flash combustion-gas chromatography using a Carlo Erba NA1500 Series 1 (CE Instruments, Milan, Italy) CN analyzer.

Adjusting Estimates for Bare Soil. The average proportion of bare soil among treatments ranged from $66 \%-83 \%$ (Table 3), which could influence treatment estimates and bias their comparisons. The model describing the distribution of organic $\mathrm{C}$ below the plant crowns and into the surrounding bare soil is affected by the root mass (Dormaar et al. 1995). The root distribution may be described by an inverted, subtended cone depending on the size of the crown because the 1-sided, lateral distribution of roots is about one-third of their depth (Schenk and Jackson 2002). Therefore, we estimated the mass of macroorganic matter and of organic $\mathrm{C}$ below bare soil as the average estimate taken below bare soil and below the crown. This follows the assumption that the least distribution was at equidistant points between plants from which the sample cores were taken.

Because the cores taken from the mixtures were combined in the field, we estimated the value of the core taken under bare soil as being equivalent to the average under bare soil of the same species grown in monoculture. This estimate was then used to solve for the below-crown estimate. Each estimate was adjusted for its representative area, whether below bare soil or the crown, and summed for the treatment total.

\section{Statistical Analyses}

Estimates of organic $\mathrm{C}$ belowground were pooled across soil increment, and only the total $(0-60 \mathrm{~cm}$ of depth) reported. Macro-organic matter was analyzed by soil increment only for the monoculture treatments. All data were analyzed with analysis of variance (ANOVA) for a randomized complete block design using the general linear model (GLM) procedure (SAS 1999). Year was considered as a split plot in the analysis of 
Table 3. Average percent foliar cover of grass species within constructed plant communities in the first, second, fourth, and fifth years after seeding $(n=4)$.

\begin{tabular}{|c|c|c|c|c|c|c|}
\hline \multirow[b]{2}{*}{ Treatment } & \multirow[b]{2}{*}{ Species } & \multicolumn{4}{|c|}{ (\% Foliar Cover) } & \multirow{2}{*}{$\frac{(\% \text { Bare Soil })}{2000}$} \\
\hline & & 1996 & 1997 & 1999 & 2000 & \\
\hline \multicolumn{7}{|l|}{ Monocultures } \\
\hline Agropyron smithii (As) & As & 34 & 56 & 81 & 52 & 76 \\
\hline Bouteloua gracilis $(\mathrm{Bg})$ & $\mathrm{Bg}$ & 57 & 54 & 54 & 45 & 71 \\
\hline Koeleria macrantha $(\mathrm{Km})$ & $\mathrm{Km}$ & 48 & 54 & 43 & 49 & 83 \\
\hline Stipa viridula (Sv) & Sv & 38 & 52 & 67 & 60 & 68 \\
\hline Elymus junceus (Ej) & $\mathrm{Ej}$ & 60 & 71 & 88 & 63 & 66 \\
\hline Agropyron cristatum (Ac) & Ac & 66 & 82 & 89 & 74 & 67 \\
\hline \multicolumn{7}{|l|}{ Mixtures } \\
\hline \multirow[t]{2}{*}{$\mathrm{As}+\mathrm{Bg}$} & As & 20 & 22 & 55 & 28 & 68 \\
\hline & $\mathrm{Bg}$ & 45 & 34 & 49 & 22 & - \\
\hline \multirow[t]{2}{*}{ As + Sv } & As & 28 & 35 & 39 & 12 & 68 \\
\hline & Sv & 22 & 27 & 57 & 46 & - \\
\hline \multirow[t]{2}{*}{$\mathrm{Bg}+\mathrm{Sv}$} & $\mathrm{Bg}$ & 55 & 53 & 57 & 23 & 66 \\
\hline & Sv & 7 & 20 & 48 & 46 & - \\
\hline \multirow[t]{3}{*}{$A s+B g+S v$} & As & 13 & 27 & 50 & 14 & 68 \\
\hline & $\mathrm{Bg}$ & 39 & 35 & 41 & 17 & - \\
\hline & Sv & 3 & 9 & 29 & 24 & - \\
\hline
\end{tabular}

aboveground primary production. Comparisons of native species mixtures with monocultures of their components were made using single degree-of-freedom contrasts. The least significant difference $\left(\mathrm{LSD}_{0.05}\right)$ values were determined for comparisons among treatment means.

\section{Species Establishment}

\section{RESULTS}

The grasses appeared to reach their maximum foliar cover by 1999 (Table 3), although the drought in 2000 (Table 2) resulted in a loss of cover among all treatments. Based on foliar cover, the introduced species established most rapidly, whereas green needlegrass and western wheatgrass tended to establish the slowest. However, both green needlegrass and western wheatgrass continued to increase until 1999 and exceeded the cover of blue grama and June grass, whereas the cover of western wheatgrass approached that of Russian wildrye and crested wheatgrass (Table 3 ).

Initial ground cover (Table 3) appeared related to the number of germinable seeds that were applied. Seed of western wheatgrass and, to a lesser extent, green needlegrass had relatively low germinability resulting in slower establishment of ground cover (Table 3). However, in monoculture treatments, both achieved equality with blue grama and June grass by the second year (1997), and in a mixture with their associated species by the third (data not shown) or fourth years (Table 3 ).

\section{Aboveground Net Primary Production}

The plant community, year of sampling, and the plant interaction all affected $(P<0.05)$ aboveground net primary production (Table 4). Of the monoculture treatments, green needlegrass and blue grama ranked first and second in above-
Table 4. Aboveground net primary production of reconstructed communities over 2 years and their stability as defined by yield reduction from a year with normal precipitation (1999) to a year with drought (2000).

\begin{tabular}{|c|c|c|c|c|}
\hline \multirow[b]{3}{*}{ Treatment } & Aboveg & ground Pro & oduction & \multirow{3}{*}{$\begin{array}{c}\text { Proportion } \\
\text { Reduction }{ }^{1} \\
(\%)\end{array}$} \\
\hline & $\begin{array}{c}2-y r \\
\text { average }\end{array}$ & 1999 & 2000 & \\
\hline & \multicolumn{3}{|c|}{$\left(\mathrm{Mg} \cdot \mathrm{ha}^{-1}\right)$} & \\
\hline Agropyron smithii (As) & 1.64 & 2.67 & 0.60 & 78 \\
\hline Bouteloua gracilis $(\mathrm{Bg})$ & 2.63 & 3.56 & 1.81 & 50 \\
\hline Koeleria macrantha (Km) & 1.30 & 1.99 & 0.62 & 68 \\
\hline Stipa viridula (Sv) & 3.11 & 4.22 & 2.01 & 51 \\
\hline Elymus junceus (Ej) & 2.36 & 3.25 & 1.46 & 54 \\
\hline Agropyron cristatum (Ac) & 1.91 & 2.47 & 1.34 & 45 \\
\hline $\mathrm{As}+\mathrm{Bg}$ Mix & 1.62 & 2.72 & 0.52 & 80 \\
\hline As + Sv Mix & 2.01 & 2.91 & 1.11 & 61 \\
\hline $\mathrm{Bg}+\mathrm{Sv}$ Mix & 2.35 & 3.49 & 1.21 & 66 \\
\hline $\mathrm{As}+\mathrm{Bg}+\mathrm{Sv}$ Mix & 1.95 & 2.98 & 0.92 & 68 \\
\hline $\mathrm{SEM}^{2}$ & 0.12 & 0.26 & 0.12 & 4.51 \\
\hline Source of Variation: & \multicolumn{4}{|c|}{ (Probability) } \\
\hline Treatment & $<0.001$ & $<0.001$ & $<0.001$ & $<0.001$ \\
\hline Year & $<0.001$ & - & - & - \\
\hline Year $\times$ Treatment & 0.034 & - & - & - \\
\hline${ }^{3} \mathrm{LSD}_{0.05}$ & 0.49 & 0.69 & 0.35 & 13.1 \\
\hline \multicolumn{5}{|l|}{ Contrasts: (Monoculture vs Mixture) } \\
\hline$(\mathrm{As}, \mathrm{Bg})$ vs. $(\mathrm{As}+\mathrm{Bg})$ & - & 0.224 & $<0.001$ & 0.001 \\
\hline$(\mathrm{As}, \mathrm{Sv}) \mathrm{vs} .(\mathrm{As}+\mathrm{Sv})$ & - & 0.111 & 0.212 & 0.591 \\
\hline$(\mathrm{Bg}, \mathrm{Sv})$ vs. $(\mathrm{Bg}+\mathrm{Sv})$ & - & 0.223 & $<0.001$ & 0.013 \\
\hline$(\mathrm{As}, \mathrm{Bg}, \mathrm{Sv})$ vs. $(\mathrm{As}+\mathrm{Bg}+\mathrm{Sv})$ & - & 0.111 & $<0.001$ & 0.111 \\
\hline
\end{tabular}

ground net primary production both in 1999 and 2000, whereas June grass was the least productive overall. Green needlegrass yielded more $(P<0.05)$ than Russian wildrye or crested wheatgrass, and blue grama yielded more $(P<0.05)$ than crested wheatgrass (Table 4). Russian wildrye was more productive $(P<0.05)$ than crested wheatgrass in 1999 . The yields of mixtures were different $(P<0.05)$ from those of monocultures in 1999 and 2000. In 1999, the yields of mixtures were similar $(P>0.05)$ to the average yields of their monocultures, but in 2000, the yields of mixtures were less $(P<0.05)$ when blue grama was present.

The reduction in aboveground net primary production from 1999 to 2000 (a drought year) was least in monocultures of blue grama, green needlegrass, Russian wildrye, and crested wheatgrass $(46 \%$ to $55 \%)$ and greatest in a monoculture of western wheatgrass and a mixture of western wheatgrass-blue grama $(78 \%$ and $81 \%$, respectively; Table 4$)$.

\section{Belowground Yield}

Macro-organic matter, which includes most of the coarse $(>0.85 \mathrm{~mm})$ live and dead root mass, in the $0-60 \mathrm{~cm}$ soil depth was similar $(P>0.05)$ between species mixtures and 


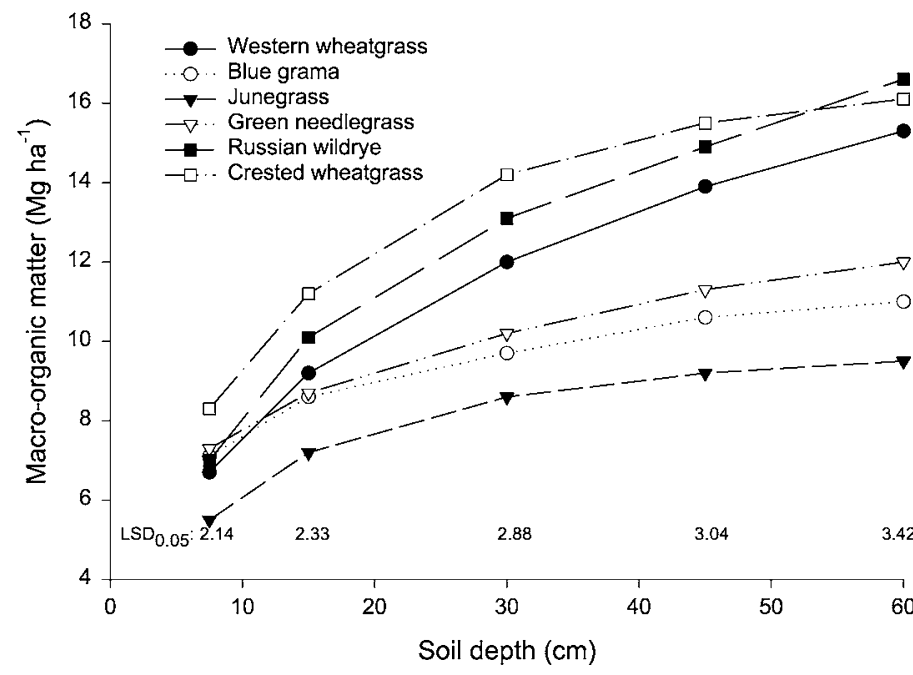

Figure 1. Distribution of macro-organic matter (0.85-mm sieve) to a depth of $60 \mathrm{~cm}$ for monoculture treatments of selected native and introduced species 5 years after seeding $(P=0.218,0.044,0.006$, 0.002 , and 0.002 for depth increments of $0-7.5 \mathrm{~cm}, 7.5-15 \mathrm{~cm}, 15-30$ $\mathrm{cm}, 30-45 \mathrm{~cm}$, and $45-60 \mathrm{~cm}$, respectively).

their monocultures (data not shown). Of the monoculture treatments, yields of macro-organic matter were greater in crested wheatgrass, Russian wildrye, and western wheatgrass than in blue grama, June grass, or green needlegrass (Fig. 1).

\section{Organic Carbon}

Organic $C$ in mineral soil, macro-organic matter, and crowns was similar $(P<0.05)$ in mixed communities to the average of their respective monocultures (Table 5). Crested wheatgrass and Russian wildrye had more $(P<0.05)$ macro-organic matter $\mathrm{C}$ than June grass and green needlegrass. Treatment effects on soil organic $\mathrm{C}$, total organic $\mathrm{C}$ (soil organic $\mathrm{C}$ plus macroorganic matter $\mathrm{C}$ ), and total organic $\mathrm{C}$ plus crown $\mathrm{C}$ were not detected $(P<0.05)$. However, in a ranking of their means according to mass, crested wheatgrass produced the least in each category, whereas blue grama produced the most in both soil organic $\mathrm{C}$ and total organic $\mathrm{C}$ (Table 5). Russian wildrye had a greater mass of crown $\mathrm{C}(P<0.05)$ than all other treatments.

\section{Establishment}

\section{DISCUSSION}

The grass species tested in our study exhibited differences in their establishment of foliar cover, production, and contributions to soil organic $\mathrm{C}$ over a 5 -year period after seeding. Foliar cover in the first year was dependent on the number of viable seeds that were applied (Table 1), but subsequent colonization appeared to be dependent on in-filling and growth. Western wheatgrass, a rhizomatous species, was seeded with the least number of germinable seeds (Table 1), but it demonstrated rapid in-filling of the plot areas and was a strong competitor in a mix (Table 3). Blue grama was seeded with a large number of seeds (Table 3 ) that ensured early establishment success. Its $\mathrm{C}_{4}$ pathway also made it more competitive under the relatively higher soil temperatures of cultivated soil. By 1999, the species composition had shifted to favor the $\mathrm{C}_{3}$ grasses, which are
Table 5. Organic carbon in soil ${ }^{1}$ and soil macro-organic matter (MOM) to a depth of $60 \mathrm{~cm}$ and in plant crowns in reconstructed plant communities.

\begin{tabular}{|c|c|c|c|c|c|}
\hline \multirow[b]{3}{*}{ Treatment } & \multicolumn{3}{|c|}{ Belowground $\mathrm{C}$} & \multirow{2}{*}{$\begin{array}{c}\begin{array}{c}\text { Above- } \\
\text { ground C }\end{array} \\
\text { Crown }\end{array}$} & \multirow[b]{2}{*}{ Total C } \\
\hline & Soil & MOM & Total & & \\
\hline & \multicolumn{5}{|c|}{$\left(\right.$ Organic C, $M g \cdot h^{-1}$ ) } \\
\hline Agropyron smithii (As) & 96.4 & 3.8 & 100.1 & 1.2 & 101.3 \\
\hline Bouteloua gracilis $(\mathrm{Bg})$ & 102.0 & 3.3 & 105.3 & 1.8 & 107.1 \\
\hline Koeleria macrantha $(\mathrm{Km})$ & 98.1 & 2.2 & 100.2 & 0.8 & 101.0 \\
\hline Stipa viridula (Sv) & 95.2 & 3.1 & 98.3 & 2.8 & 101.1 \\
\hline Elymus junceus (Ej) & 96.3 & 4.3 & 100.5 & 7.2 & 107.8 \\
\hline Agropyron cristatum (Ac) & 90.6 & 4.3 & 94.9 & 1.0 & 95.9 \\
\hline $\mathrm{As}+\mathrm{Bg}$ Mix & 101.3 & 3.9 & 105.6 & 0.8 & 106.4 \\
\hline As + Sv Mix & 98.3 & 3.7 & 102.0 & 1.0 & 103.0 \\
\hline $\mathrm{Bg}+\mathrm{Sv}$ Mix & 94.1 & 3.3 & 97.4 & 1.7 & 99.1 \\
\hline $\mathrm{As}+\mathrm{Bg}+\mathrm{Sv}$ Mix & 101.7 & 3.8 & 105.5 & 1.4 & 106.9 \\
\hline SEM $^{2}$ & 3.30 & 0.41 & 3.32 & 0.63 & 3.25 \\
\hline Source of Variation: & \multicolumn{5}{|c|}{ (Probability) } \\
\hline Treatment & 0.303 & 0.038 & 0.332 & $<0.001$ & 0.194 \\
\hline${ }^{3} \mathrm{LSD}_{0.05}$ & 9.58 & 1.18 & 9.64 & 1.84 & 9.42 \\
\hline \multicolumn{6}{|l|}{ Contrasts: (Monocultures vs Mix) } \\
\hline$(\mathrm{As}, \mathrm{Bg})$ vs $(\mathrm{As}+\mathrm{Bg})$ & 0.535 & 0.479 & 0.483 & 0.400 & 0.578 \\
\hline$(\mathrm{As}, \mathrm{Sv})$ vs $(\mathrm{As}+\mathrm{Sv})$ & 0.535 & 0.632 & 0.501 & 0.214 & 0.656 \\
\hline$(B g, S v)$ vs $(B g+S v)$ & 0.274 & 0.848 & 0.287 & 0.452 & 0.218 \\
\hline$(\mathrm{As}, \mathrm{Bg}, \mathrm{Sv})$ vs $(\mathrm{As}+\mathrm{Bg}+\mathrm{Sv})$ & 0.327 & 0.394 & 0.282 & 0.486 & 0.333 \\
\hline
\end{tabular}

${ }^{1}$ Macro-organic matter removed.

${ }^{2}$ SEM indicates standard error of the mean.

${ }^{3}$ LSD indicates least significant difference.

more competitive in the Northern Great Plains because they begin growth earlier in spring when soil moisture is generally more available and soil temperatures are below optimal for blue grama. Introduced species have undergone breeding for improved seed germination and establishment, which resulted in a large proportion of germinable seeds (Table 1) and rapid establishment of foliar cover (Table 3).

The drought conditions in 2000 (Table 2) reduced the canopy cover of most species and, in particular, that of western wheatgrass, which was the only rhizomatous species included in our study. Zhang and Romo (1995) reported either no tiller recruitment or severely reduced tiller survival in northern wheatgrass (A. dasystachyum [Hook.] Scribn.) plants subject to $70 \%$ of average precipitation, whereas drought had a relatively greater effect on western wheatgrass than on blue grama (Eneboe et al. 2002). After establishment, compositional shifts within a community continued to be influenced by environmental changes and interspecies competitive effects. Within mixed communities of our study, western wheatgrass tended to become more competitive with greater soil moisture, whereas the tufted species were favored by more xeric conditions.

\section{Aboveground Yields}

We could find no published estimates from the Northern Great Plains to support our observations that blue grama was more productive than crested wheatgrass. Blue grama tends to 
contribute a minor proportion to the total aboveground net primary production in the Mixed Prairie communities of Canada (Coupland 1950). As such, it reflects a lack of competitiveness with associated cool-season species that include western wheatgrass and green needlegrass. Nevertheless, on some Mixed Prairie sites, sustained grazing pressure can shift the community toward one dominated by blue grama (Coupland 1961). Although these communities are resistant to encroachment by climax-dominant species after grazing pressure has been removed and are highly stable, they tend to be unproductive (Coupland 1950). Conversely, the yields of crested wheatgrass and Russian wildrye, relative to those of native species, were less than has been reported when compared with seeded monocultures (Kilcher and Looman 1983) or with native communities (Smoliak and Slen 1974; Smoliak and Dormaar 1985).

These apparent anomalies are at least partly related to the effect of site. Four blue grama varieties grown in a nursery yielded an average of $2.2 \mathrm{Mg} \cdot \mathrm{ha}^{-1}$ in the Southern Great Plains (Pitman and Jaynes 1980), thus illustrating the potential of this species when given suitable site conditions. Similarly, the 5-year average yields of crested wheatgrass and Russian wildrye were 2.1 and 1.4 times the yields from a semiarid site dominated by needle-and-thread (Stipa comata Trin. + Rupr.) and blue grama (W. D. Willms, unpublished data, 2004). This site is in the same vicinity from which other data in published reports were derived (Smoliak and Slen 1974; Smoliak and Dormaar 1985), and this study supports their observations of greater yields from crested wheatgrass and Russian wildrye than from native communities. However, the same species produced only 0.8 and 0.7 times the yields from a more mesic site dominated by green needlegrass and western wheatgrass, which was in the same vicinity as the current study. Black (1968) reported an interaction of relative yields between crested wheatgrass and a native community, which consisted of $55 \%$ western wheatgrass and $20 \%$ each of green needlegrass and blue grama, with precipitation. In that study, the native community was more productive than the crested wheatgrass in a year of favorable moisture and less productive when moisture levels were below average. In the current study, Russian wildrye, which produced greater yields than crested wheatgrass, also performed relatively better than native mixtures during drought; but the aboveground net primary production of both species were less than the monocultures of either green needlegrass or blue grama (Table 4).

We found no evidence of overyielding in mixtures of 2 or 3 species (Table 4), which is contrary to what Tilman et al. (2001) and Hector et al. (1999) observed for plots with considerably greater species richness and functional diversity. In our study, the productive advantage of a monoculture was more evident during drought for green needlegrass and blue grama but not for western wheatgrass. Of these species, western wheatgrass is more deep rooted and avoids drought by reducing leaf area. whereas the tufted species may be more efficient in capturing rainfall (Ndawula-senyimba et al. 1971), an attribute that becomes important during periods of drought.

\section{Response to Drought}

Production stability, estimated as the change in aboveground net primary production from normal moisture (1999) to drought (2000) conditions, of 3 functionally diverse, native grass species (western wheatgrass, blue grama, and green needlegrass) was less for simple mixtures than their monocultures (Table 4). This phenomenon was particularly acute for mixtures that included western wheatgrass or blue grama and, when both occurred together in a dual mixture, resulted in the greatest yield reduction $(80 \%)$ from 1999 to 2000 of any treatment (Table 3). Nevertheless, as a monoculture, blue grama exhibited the greatest stability for this period, whereas western wheatgrass exhibited the least.

The apparently similar responses of 2 functionally distinct species in mixtures to drought likely have different causes. Western wheatgrass, a deep-rooted $\mathrm{C}_{3}$ species, uses available soil moisture in spring and responds to drought by suppressing tillering (Zhang and Romo 1995), thereby reducing foliar cover and yields of standing crop. However, blue grama, a $\mathrm{C}_{4}$ that is more shallow rooted (Fig. 1), begins growth several weeks later, when soil moisture has been further depleted, than the coolseason grasses, thereby limiting aboveground net primary production. In a mature community, niche separation between the 2 species is likely based more on temperature than moisture gradients (Kemp and Williams 1980).

\section{Macro-Organic Matter and Organic C}

The greater mass of macro-organic matter in crested wheatgrass and Russian wildrye than in the tufted native species (Fig. 1) is contrary to studies that report similar or less root mass in crested wheatgrass than in shortgrass (Redente et al. 1989) or Mixed Prairie (Dormaar et al. 1978; Smoliak and Dormaar 1985) grasslands. This may be explained by one or more factors relevant to our study; one is the relatively short period that our plots were established and the incomplete time for the treatments to achieve their potential expression. The species effects on soil organic constituents were the net result produced by growth and decomposition after the treatments were established. Because root turnover on the Mixed Prairie may be only $18 \%$ per year (Sims and Coupland 1978), root mass accumulates until a steady state is reached. In our study, a steady state had likely not been achieved 5 years after seeding, and rates of community establishment would have affected the mass of organic constituents in soil. First-year establishment, as measured by canopy cover, appeared to be more rapid in crested wheatgrass and Russian wildrye than in the native grass treatments (Table 3). A second factor may be the simple nature of our reconstructed communities and the diminished complementarity produced by species that were functionally more similar than might be expected in a native community. For example, we had no annual species or legumes that might occupy a unique niche or facilitate production among plants.

The large mass of macro-organic matter in crested wheatgrass and Russian wildrye was not reflected in more organic $\mathrm{C}$ in the soil (Table 5). On the contrary, average yields of soil organic $\mathrm{C}$ were less $(P>0.05)$ in crested wheatgrass than in blue grama. These 2 species represented the low and high values among the 10 communities tested (Table 5). The difference, although not significant $(P>0.05)$, may originate from fine roots that were not removed by sieving or, possibly, from microbial mass supported by root exudates. These hypotheses are supported by evidence that indicates blue grama has a greater proportion of fine roots than crested wheatgrass (Dormaar et al. 1995) and produces more root exudates (Biondini et al. 1988). 


\section{Management Implications}

The effectiveness of native plants in reclamation projects must be evaluated in relation to the species and their mixtures and assessed against the objective of their application. We evaluated the production and effects on soil quality of 4 native grass species that are common on the Dark Brown Chernozemic soil of the Mixed Prairie and compared them with 2 introduced grasses that are recommended for the region. Results from our study led to 2 general conclusions: 1) simple mixtures of native species cannot be expected to yield more aboveground primary production or yield more soil organic $\mathrm{C}$ than monocultures of their components, and 2) native species may yield similar or greater aboveground primary production than the introduced grasses. Reconstructed communities, having simple mixtures of native grass species, tended to produce less aboveground biomass, which was more vulnerable to drought than monocultures of those species, whereas soil organic $\mathrm{C}$ was similar between them. However, the relatively short period of the study may have mitigated the detection of treatment effects, which might become more apparent as the soil composition approaches equilibrium with its plant community.

\section{ACKNOWLEDGMENTS}

The authors are grateful for the assistance of Bryan Farries and his field crew for plot establishment and maintenance and to Ryan Beck, Nancy Lee, and Clarence Gilbertson for soil and vegetation sampling, sample preparation, and analyses.

\section{LITERATURE CITED}

Alberta Agriculture, Food and Rural Development. 2001. Establishing perennial hay and pasture crops. Edmonton, Alberta. Agdex 120/22-2. 8 pp.

Biondini, M., D. A. Klein, and E. F. Redente. 1988. Carbon and nitrogen losses through root exudation by Agropyron cristatum, A. smithii, and Bouteloua gracilis. Soil Biology and Biochemistry 20:477-482.

BLACK, A. L. 1968. Nitrogen and phosphorus fertilization for production of crested wheatgrass and native grass in northeastern Montana. Agronomy Journal 60:213-216.

Coupland, R. T. 1950. Ecology of Mixed Prairie in Canada. Ecological Monographs 20:271-315.

Coupland, R. T. 1961. A reconsideration of grassland classification in the Northern Great Plains of North America. Journal of Ecology 49:135-167.

DaubenmiRe, R. F. 1959. A canopy-coverage method of vegetational analysis. Northwest Science 33:43-64.

Dormaar J. F., A. M. Johnston, and S. Smoliak. 1978. Long-term soil changes associated with seeded stands of crested wheatgrass in southeastern Alberta, Canada, p. 623-625. In: D. N. Hyder [ed.]. Proceedings of the 1st International Rangeland Congress; 14-18 August 1978; Denver, C0: Society for Range Management.

Dormaar, J. F., M. A. Naeth, W. D. Willms, and D. S. Chanasyk. 1995. Effect of native prairie, crested wheatgrass (Agropyron cristatum [L.] Gaertn.) and Russian wildrye (Elymus junceus Fisch.) on soil chemical properties. Journal of Range Management 48:258-263.

Eneboe, E. J., B. F. Sowell, R. K. Heitschmidt, M. G. Karl, and M. R. Haferkamp. 2002. Drought and grazing: IV. blue grama and western wheatgrass. Journal of Range Management 55:73-79.
Hector, A., B. Schmid, C. Beierkuhnlein, M. C. Caldeira, M. Diemer, P. G. Dimitrakopoulos, J. A. Finn, H. Freitas, P. S. Giller, J. Good, R. Harris, P. Högberg, K. Huss-Danell, J. Joshi, A. Jumpponen, C. Körner, P. W. Leadley, M. Loreau, A. Minns, C. P. H. Mulder, G. O’Donovan, S. J. Otway, J. S. Pereira, A. Prinz, D. J. Read, M. Scherer-Lorenzen, E.-D. Schulz, A.-S. D. Siamantziouras, E. M. Spehn, A. C. Terri, A. Y. Troumbis, F. I. Woodward, S. Yachi, and J. H. Lawton. 1999. Plant diversity and productivity in European grasslands. Science 286: 1123-1127.

Kemp, P. R., AND G. J. WiLliams III. 1980. A physiological basis for niche separation between Agropyron smithii $\left(\mathrm{C}_{3}\right)$ and Bouteloua gracilis $\left(\mathrm{C}_{4}\right)$. Ecology 61: 846-858.

KerR, D. S., L. J. Morrison, And K. E. Wilkinson. 1993. Reclamation of native grasslands in Alberta: A review of the literature. Alberta Land Conservation and Reclamation Council Report No. RRTAC 93-1. ISBN 0-7732-0881-X. 205 p. plus Appendices.

KILCHER, M. R., AND J. Looman. 1983. Comparative performance of some native and introduced grasses in southern Saskatchewan, Canada. Journal of Range Management 36:654-657.

LaWrence, T., And C. D. Ratzlaff. 1989. Performance of some native and introduced grasses in a semiarid region of western Canada. Canadian Journal of Plant Science 69:251-254.

Lesica, P., and T. H. Deluca. 1996. Long-term harmful effects of crested wheatgrass on Great Plains grassland ecosystems. Journal of Soil and Water Conservation 51:408-409.

Ndawula-Senyimba, M. S, V. C. Brink, and A. McLean. 1971. Moisture interception as a factor in the competitive ability of bluebunch wheatgrass. Journal of Range Management 24:198-200.

Pitman, W. D., And C. C. Jaynes. 1980. Strains of blue grama and sideoats grama evaluated for the Southern Great Plains. Journal of Range Management 33: 381-384.

Redente, E. F., M. E. Biondini, and J. C. Moore. 1989. Observations on biomass dynamics of a crested wheatgrass and native shortgrass ecosystem in southern Wyoming. Journal of Range Management 42: $113-118$.

Romo, J. T., AND T. HarRison. 1999. Regrowth of crested wheatgrass (Agropyron cristatum [L.] Gaertn.) following defoliation Canadian Journal of Plant Science 79:557-563.

[SAS] SAS InStitute Inc. 1999. SAS/STAT Users Guide. Version 8. Cary, NC: SAS Institute Inc. $3884 \mathrm{p}$.

SCHENK, J., AND R. B. JACKSON. 2002. Rooting depths, lateral root spreads ad belowground/aboveground allometries of plants in water limited ecosystems. Journal of Ecology 90:480-494.

Sims, P. L., and R. T. Coupland. 1978. Producers. In: R. T. Coupland [ed.]. Grassland ecosystems of the world. New York, NY: Cambridge University Press. p. 49-72.

Smoliak S., AND J. F. Dormaar. 1985. Productivity of Russian wildrye and crested wheatgrass and their effect on prairie soils. Journal of Range Management 38:403-405.

SmoliAK, S., AND S. SLEN. 1974. Beef production on native range, crested wheatgrass, and Russian wildrye pastures. Journal of Range Management 27:433-436.

Tilman, D., P. B. Reich, J. Knops, D. Wedin, T. Mielke, and C. Lehman. 2001. Diversity and productivity in a long-term grassland experiment. Science 294:843-845.

Watson, L. E., R. W. Parker, and D. F. Polster. 1980. Manual of Species Suitability for Reclamation in Alberta. Alberta Land Conservation and Reclamation Council Report \#RRTAC 80-5. 2 vols. 541 p.

Zhang, J., AND J. T. Romo. 1995. Impacts of defoliation on tiller production and survival in northern wheatgrass. Journal of Range Management 48: $115-120$. 